\title{
GÖRDÜLÉSI ELLENÁLLÁS HATÁSÁNAK MODELLEZÉSE DISZKRÉT ELEMEK MÓDSZERÉVEL
}

\section{DISCRETE ELEMENT MODELING OF WHEEL ROLLING RESISTANCE}

\author{
Bablena Adrienn \\ NAIK Mezögazdasági Gépesitési Intézet, H-2100 Magyarország, Gödöllö, Tessedik \\ Sámuel utca 4.; Tel.: +36 28511 689; E-mail: bablena.adrienn@gmgi.hu
}

\begin{abstract}
In discrete element modeling variation of horizontal and vertical forces and the moment of rolling resistance were examined at the beginning of pure rolling and steady-state condition. Breaking force and the moment of rolling friction have maximum values at the start of rolling which are significantly greater than steady-state values. Ratio of horizontal and vertical forces is around 0,25 in a wide range of micromechanical parameters.
\end{abstract}

Keywords: modeling, discrete element method, rolling resistance.

\section{Összefoglalás}

A talaj-kerék kapcsolat diszkrét elemes modellezése során megvizsgáltuk a kerékre ható vízszintes és függőleges irányú fékezőerők, valamint a gördülési ellenállás nyomatékának változását a csúszásmentes gördülés kezdetén, valamint állandósult állapot esetén. Mind a fékezőerő, mind a gördülési ellenállás nyomatéka egy, az állandósult állapotnál jelentősen nagyobb indítási maximummal rendelkezik. A vízszintes és függőleges irányban keletkező fékezőerő aránya a mikromechanikai paraméterek széles tartományában 0,25 körüli értéken állandósul.

Kulcsszavak: modellezés, diszkrét elemek módszere, gördülési ellenállás.

\section{Bevezetés}

Talajon mozgó jármüvek esetében a talaj és a kerék közötti kapcsolat mechanikai modellezése rendkívül bonyolult feladat. Mind a talaj, mind a deformálható kerék önmagában is olyan bonyolultságú mechanikai rendszer, melyek összetettsége a gyakorlat számára kielégítő pontosságú mechanikai modellek létrehozását jelentősen megnehezíti.
Az 1900-as évek elején Bernstein [3] foglalkozott a gördülési ellenállás meghatározásával. Bekker [2] szerint az általa megfogalmazott következtetések nehezen általánosíthatók, mivel hiányoznak belölük a talaj feszültségi és alakváltozási állapotával kapcsolatos információk.

Merev kerék „,talajon” történő mozgását befolyásoló gördülési ellenállást elméletben kizárólag az érintkező felületek között kialakuló feszültségi és deformációs állapot határozza meg [2]. 
Sitkei [8] kísérleti és analitikus talajkerék modelljében elsősorban a talaj alakváltozási és tönkremeneteli tulajdonságai határozzák meg a talaj-kerék kapcsolat során kialakuló erőket.

A talaj-gumiabroncs kapcsolat numerikus modellezésére a végeselem módszer a legelterjedtebb, mely lehetővé teszi anyagi és geometriai nemlinearitás és ortotróp anyagmodell feltételezésével a deformálható kerékmodell elkészítését. A talaj modellezése, a nagy alakváltozások és a talaj elnyíródásának problémája nehezen megoldható, mivel végeselem módszer segítségével a talajt csak kontinuumként lehet kezelni [4] [9].

Az utóbbi időszakban elterjedt diszkrét elemes módszer (DEM) lehetővé teszi a deformálható talajmodell létrehozását, azonban ezzel a módszerrel a deformálható kerék nehezen modellezhető [6] [7].

\section{Anyag és módszer}

Ebben a munkában a talaj által kifejtett, a kereket fékező gördülési ellenállás numerikus modellezésének lehetőségeit kívánom megvizsgálni. A fent bemutatott két lehetséges módszer közül a diszkrét elemek módszerét alkalmazom.

\subsection{Diszkrét elemek módszere}

A diszkrét elemek módszere egy numerikus módszer, mely kifejezetten szemcsés anyagok vizsgálatára jött létre a 70-es években. Minden diszkrét elemes modell különálló elemekből és az elemek érintkezésével létrejövő kapcsolatokból áll. Egy eljárást akkor nevezhetünk diszkrét elemes modellnek, ha [1]:

- egymástól egyértelmüen elkülönülő elemekböl épül fel;

- az elemek önálló elmozdulási szabadságfokokkal rendelkeznek oly módon, hogy a modell képes követni az elemek véges nagyságú eltolódásait és deformációit;
- az elemek között új kapcsolatok jöhetnek létre és meglévő kapcsolatok szünhetnek meg.

A diszkrét elemes módszer müködésének alapja az, hogy a halmaz mechanikai viselkedését a halmazt alkotó egyes szemcsék mozgásállapotának nyomon követésével modellezi. A módszer alkalmazása során az egymással, a falakkal és a kerékkel kölcsönhatásba lépő egyes szemcsékre kell a lendület- és a perdülettétel alapján felírt differenciálegyenleteket numerikusan megoldani.

\subsection{Talaj-kerék kapcsolat diszkrét elemes modellje}

A talaj-kerék kapcsolat diszkrét elemes modelljében egy $150 \mathrm{~mm}$ átméröjü, $40 \mathrm{~mm}$ szélességü merev korongot használtunk kerékként. A szemcséket egy 350x300x40 méretü téglatest alakú tartományban helyeztük el, a tartományt a szimuláció első lépéseként véletlenszerüen kitöltöttük 1,6 és $2 \mathrm{~mm}$ között véletlenszerüen változó sugarú gömbökkel, melyek gravitációs ülepedés után körülbelül 1/3 magasságig feltöltötték a vizsgálati tartományt (1.ábra). A szimulációhoz „Hertz-Mindlin with bonding" modellt alkalmaztunk.

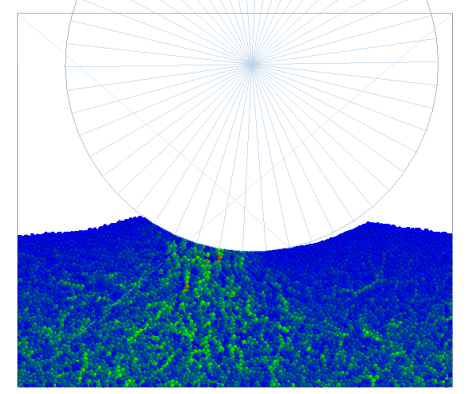

1. ábra. Talaj-kerék kapcsolat diszkrét elemes modellje 
A modellezés során használt mikromechanikai paraméterek az alábbiak [5]:

- Poisson tényező: 0,25 (talaj), 0,45 (kerék);

- nyírási modulus: 1e7 $P a$ (talaj), 1e6 $P a$ (kerék);

- sűrüség: $3000 \mathrm{~kg} / \mathrm{m}^{3}$ (talaj), $910 \mathrm{~kg} / \mathrm{m}^{3}$ (kerék);

- normál merevség: $1 \mathrm{e} 9 \mathrm{~N} / \mathrm{m}$;

- nyíró merevség: 1e9 $\mathrm{N} / \mathrm{m}$;

- kritikus normál feszültség: 1 e5 $P a$;

- kritikus nyírófeszültség: 5e4 $P a$;

- kötési sugár: $6 \mathrm{~mm}$;

- ütközési tényező: 0,5 (talaj-talaj, talajkerék);

- súrlódási tényező: 0,5 (talaj-talaj), 0,8 (talaj-kerék);

- gördülési ellenállási tényező: 0,01 (talajtalaj), 0,05 (talaj-kerék).

A 2. ábrán egy szimulációból kapott kerékre ható, a kerék síkjára merőleges tengelyre számított gördülési ellenállási nyomaték értékét láthatjuk. A diagram három fó szakaszra bontható: a benyomódási szakaszban a kereket függőleges irányban a talaj felszínére helyezzük. A függőlegesen lefelé mozgó kerékre ható nyomaték a kezdeti szakaszban jelentős hullámzást mutat, majd a talajfelszín kezdeti (az egyes szimulációk során véletlenszerúen kialakuló) alakjától függően valamilyen pozitív vagy negatív értéket vesz fel. Ezután a kereket tiszta gördülő mozgásba hozzuk. A kerék mozgását a talajszemcsék a 2. ábrán látható módon akadályozzák. Ez a fékező hatás a kerékre ható nagyszámú koncentrált erő formájában jelentkezik, amely kapcsolati erőhálózat az 1. ábrán látható. Ezek a koncentrált erők fékezőnyomatékot is kifejtenek a forgó, tisztán gördülő mozgást végző korongra. Láthatjuk a 2. ábrán, hogy ez a fékezőnyomaték a kerék indítását követően felvesz egy maximális értéket, amely később csökkenni kezd, majd egy minimum után újra növekedésnek indul.

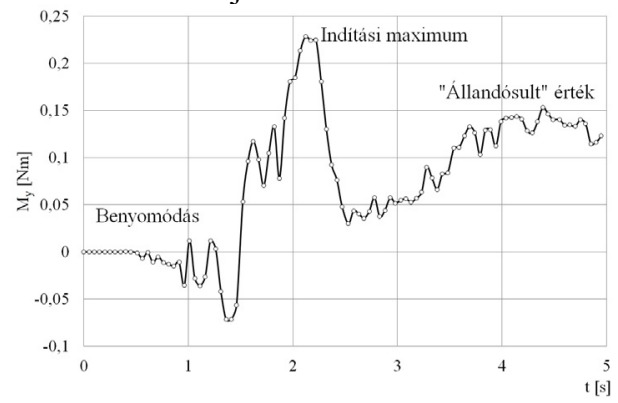

2. ábra. A gördülési ellenállás nyomatéka

Ez a növekedés azonban a továbbiakban már nem éri el a kezdeti maximális értéket, hanem egy annál kisebb értéken állandósul. Ezt az állandósult értéket tekinthetjük a gördülési ellenállás nyomatékának. A gyakorlat számára fontos lehet annak ismerete, hogy a talajon mozgó jármüvek indítási nyomatékigénye milyen mértékben haladja meg a későbbi haladó mozgás során fellépő gördülési ellenállás leküzdéséhez szükséges nyomaték értékét.

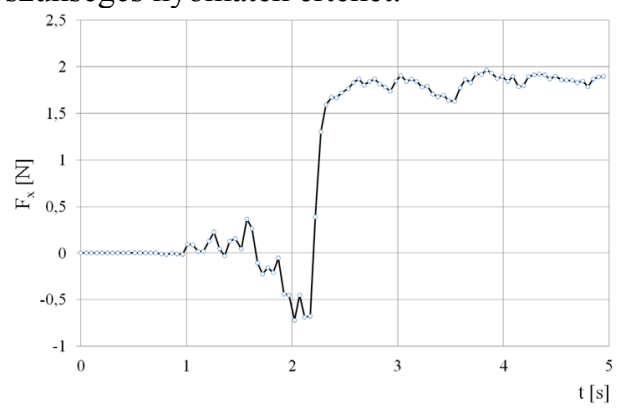

3. ábra. A mozgás irányában keletkezö erö

A 3. és 4. ábrán a kerékre ható függőleges és vízszintes erőket láthatjuk. Ezeken a diagramokon is megjelenik az indítás elötti benyomódásból származó változás. 


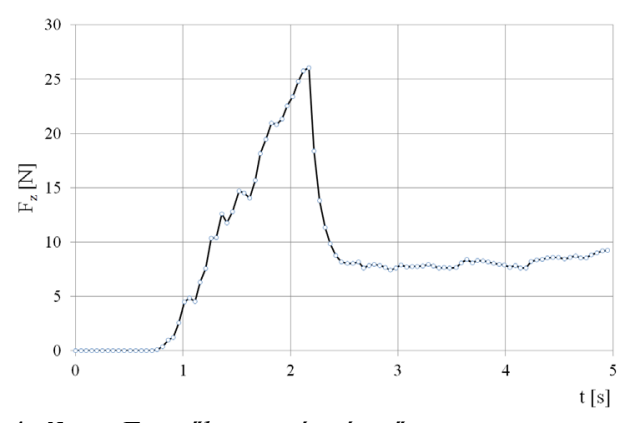

4. ábra. Függőleges irányú erő

Itt is megjelenik az indítás pillanatához tartozó csúcsérték, majd a gyors csökkenés az állandósult állapothoz tartozó értékre.

Megvizsgáltuk a kohezív kötések számának alakulását is. Azt tapasztaltuk, hogy az eddig vizsgált tiszta gördülés során a kohezív kötések száma nem változik.

Megvizsgáltuk az $F_{x} / F_{z}$ érték változását a mikromechanikai paraméterek függvényében. Több szimulációt is elvégezve arra az eredményre jutottunk, hogy ez az érték a mikromechanikai paraméterek széles tartományában 0,25 körüli értéket vesz fel.

\section{Következtetések}

A diszkrét elemes módszer (az analitikus eljárásokkal szemben) alkalmas az időben változó kölcsönhatási folyamatok modellezésére is. Így lehetőség nyílik ezen kölcsönhatási folyamatok dinamikusan változó pillanatnyi értékeinek elemzésére.

A tiszta gördülés során a szimulációban kialakult kohezív kötések száma nem változik.

Az $F_{x} / F_{z}$ viszony a mikromechanikai paraméterek széles tartományában 0,25 érték körül állandósul.

\section{További feladatok}

Célom egy jól használható numerikus talaj-kerék kapcsolati modell létrehozása merev kerék - deformálható talaj, valamint deformálható kerék - merev talaj kapcsolat modellezésére. A továbbiakban egyrészt létre kell hoznom egy jól kalibrált talajmodellt. El kell végeznem az előbbiekben bemutatott erő és nyomaték értékek érzékenységvizsgálatát a mikromechanikai paraméterekre, majd faktoriális kísérlet felhasználásával kiválasztani azokat a mikromechanikai jellemzőket, amelyek leginkább hatással vannak a vizsgált kölcsönhatási folyamatra.

\section{Szakirodalmi hivatkozások}

[1] Bagi, K.: Diszkrét elemek módszere, Budapesti Müszaki Egyetem egyetemi jegyzet, Budapest, 2007. 73.

[2] Bekker, M. G.: Theory of land locomotion, University of Michigan Press, Michigan, 1956. 520.

[3] Bernstein, R.: Probleme zur experimentellen motorpflugmechanik, Der Motorwagen, Vol. 16, No. 1, 1913. 199-227.

[4] Fervers, C. W.: Improved FEM simulation model for tire-soil interaction, Journal of Terramechanics Vol. 41, No. 2-3, 2004. 87100.

[5] Keppler, I., Hudoba, Z., Oldal, I., Csatar, A., Fenyvesi, L.: Discrete element modeling of vibrating tillage tools, Engineering Computations, Megjelenés alatt, 2015.

[6] Knuth, M. A., és mások: Discrete element modeling of a Mars Exploration Rover wheel in granular material, Journal of Terramechanics Vol. 49, No. 1, 2012. 27-36.

[7] Nakashima, H., és mások: Parametric analysis of lugged wheel performance for a lunar microrovel by means of DEM, Journal of Terramechanics Vol. 44, No. 2, 2007. 153-162.

[8] Sitkei, Gy.: A talaj-kerék kapcsolat néhány elméleti kérdése, Székfoglalók a Magyar Tudományos Akadémián, Budapest, 1998. $1-16$.

[9] Xia, K.: Finite element modeling of tire/terrain interaction: Application to predicting soil compaction and tire mobility, Journal of Terramechanics Vol. 48, No. 2, 2011. 113-123. 